\title{
НОВІ ВИЯВИ ЖАРГОННОЇ ЛЕКСИКИ НА ПОЗНАЧЕННЯ НЕГАТИВНИХ ПРОЦЕСІВ У МОВІ СУЧАСНОЇ УКРАЇНСЬКОЇ ПУБЛІЦИСТИКИ
}

\author{
ЮЛІЯ КАЛУЖИНСЬКА \\ ДВНЗ „Переяслав-Хмельницький Державний педагогічний університет \\ імені Григорія Сковороди", м. Переяслав-Хмельницький — Україна \\ NOWE PRZEJAWY LEKSYKI ŻARGONOWEJ \\ NA OZNACZENIE PROCESÓW NEGATYWNYCH \\ W JĘZYKU WSPÓŁCZESNEJ PUBLICYSTYKI \\ JULIA KAŁUŻYŃSKA \\ Państwowa Szkoła Wyższa „Perejasław-Chmielnicki Państwowy Uniwersytet \\ Pedagogiczny im. Hryhorija Skoworody", Perejasław-Chmielnicki — Ukraina
}

STRESZCZENIE. W artykule rozpatrzono nowe przejawy leksyki żargonowej na oznaczenie procesów negatywnych w języku mediów drukowanych. Podjęto próbę grupowania i usystematyzowania jednostek żargonowych według zakresu ich zastosowania. Zdefiniowano rolę słownictwa żargonowego w języku mediów drukowanych, rozpatrzono oddziaływanie czynników pozajęzykowych na język publicystyki ukraińskiej.

\section{NEW DETECTS OF SLANG FOR MARKING NEGATIVE PROCESSES IN THE LANGUAGE OF MODERN UKRAINIAN PERIODICALS}

\section{YULIIA KALUZHYNSKA}

SHEE "Hrygoriy Skovoroda Pereyaslav-Khmelnytsky State Pedagogical University", Pereyaslav-Khmelnytsky — Ukraine

ABSTRACT. The article deals with the new detects of slang for marking negative processes in the language of mass media. The effort to group and systematize slang by the sphere of its use has been made. The stylistic role of slang in the language of modern periodicals is defined, the influence of extra linguistic factors on the language of Ukrainian periodicals has been analyzed.

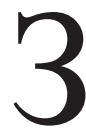

асоби масової інформації є одним з елементів громадського життя, що активно реагує на суспільні процеси, віддзеркалює їх, впливає на свідомість людей. Здатність швидко й майже повністю охоплювати найширші аудитоpiї дає їм змогу формувати суспільну думку, визначати духовні цінності і под.

За роки незалежності України, метою яких були демократизація суспільства, скасування цензури, зняття суворих стильових норм, розпочалася лібералізація газетної мови, посилилися надходження зниженої лексики в мову преси. Подібні зміни притягували увагу багатьох лінгвістів. О. Тараненко ${ }^{1}$ стверджує, що вони були викликані прагненням значної частини суспільства і 3МI до більшої простоти мовлення.

${ }^{1}$ О. О. Тараненко, Колоквіалізація, субстантивація та вульгаризація як характерні явищза стилістики сучасної української мови (з кіния 1980-х рр.), [в:] „Мовознавство” 2002, № 4-5, c. 35 . 
Особливості газетної мови розглядали провідні українські дослідники, зокрема такі мовознавці, як: А. Васильєва ${ }^{2}$, Н. Голікова ${ }^{3}$, М. Жовтобрюх ${ }^{4}$, Н. Линник ${ }^{5}$, Л. Масенко 6 , О. Пономарів ${ }^{7}$, О. Сербенська ${ }^{8}$ та ін.

Соціально-політичні процеси останніх років обумовили зміни в лексикосемантичній системі української мови. Дев'яності роки XX ст. започаткували новий етап поступу української мови. Політичні, економічні, соціокультурні зміни стали одним з основних чинників потужного „жаргонного вибуху”. . Відмова від бюрократичних елементів „канцеляриту” викликала потребу в заповненні утворених лакун елементами інших стилістичних шарів, зокрема уснорозмовною та жаргонною лексикою. Це призвело до активного використання жаргонних одиниць у мові української періодики, де для відображення фактів і подій та супровідної оцінки експресивно-оцінна лексика відіграє значну роль саме тому, що номінативна функція жаргонізмів тісно пов'язана з образністю, ïx і використовують у мові газети для надання описуваним фактам і подіям певної оцінки.

Мова сучасних газет підвищено експресивна. Експресивна функція набуває нових виявів у вживанні стилістично зниженої лексики, що має потужний експресивно-емоційний потенціал. Дослідженню цього шару лексики, умовам iii функціонування в сучасному газетно-публіцистичному дискурсі присвячені праці вітчизняних та зарубіжних учених. Цей напрям репрезентують в україністиці праці В. Балабіна ${ }^{10}$, Р. Бесаги ${ }^{11}$, Б. Коваленка ${ }^{12}$, С. Мартос ${ }^{13}$, А. Семіва ${ }^{14}$; на матеріалі російської мови - насамперед такі українські дослідники, як Л. Кудрявцева ${ }^{15}$ та Л. Синельникова ${ }^{16}$.

Жаргонізми використовують певні соціальні групи, але сьогодні ними активно оперують і журналісти. Характерним для періодичних видань $є$ використання одиниць, що мають статус кримінального жаргону (иuтu ${ }^{17}$ — „необгрунтовано звинувачувати когось у чомусь”; мокрий ${ }^{18}$ — „пов’ язаний з убивством,

${ }^{2}$ А. Н. Васильева, Газетно-публицистический стиль, Москва 1982, с. 198.

${ }^{3}$ Н. С. Голікова, Етикет і культура мовного спілкування у вищій школі, Дніпропетровськ 2009, c. 157.

${ }^{4}$ М. А. Жовтобрюх, Мова української періодичної преси (кінецьь XIX-початок XX cm.), Київ 1970, с. 304.

${ }^{5}$ Н.В.Линник, Вживання зниженої лексики у мові друкованих засобів масової інформації та ï̈ вплив на норми літературної мови, [в:] „Культура народов Причерноморья” 2004, № 49, с. 65- 67.

6 Л. Т. Масенко, Мова і політика, Київ 1999, с. 100.

${ }^{7}$ О. Д. Пономарів, Стилістика сучасної украӥнської мови, Київ 1993, с. 19-20.

${ }^{8}$ О. А. Сербен ська, Нові тенденції у мові сучасної преси, Київ 1998, с. 106.

9 Л. О. Ставицька Український жаргон. Словник, Київ 2005, с. 12

${ }^{10}$ В. В. Балабін, Сучасний американський військовий сленг як проблема перекладу, Київ 2002 , c. 315.

${ }^{11}$ Р. В. Бесага, Нестандартизовані елементи в украйнській літературній мові, Ужгород 1996, c. 241.

12 Б. О. Коваленко, Стилістично занижена лексика в мові сучасної украӥнської публіцистики, Кам'янець-Подільський 2002, с. 182.

${ }^{13}$ C. А. Мартос, Молодіжний сленг у мовленнєвій структурі м. Херсона, Херсон 2006, с. 244.

${ }^{14}$ A. Р. С емів, Структурні та семантико-стилістичні особливості лексики арго у сучасній франиузькій мові (на матеріалі мови преси), Київ 2001, с. 19.

${ }_{15}$ Л. А. Кудрявцева, Сучасні аспекти дослідження мас-медійного дискурсу: експресія вилив — маніпуляція, [в:] „Мовознавство” 2005, № 1, с. 58-66.

${ }^{16}$ Л. Н. Синельникова, Когнитивно-языковая характеристика современного лирического сюжета, Краснодар 1994, с. 438.

${ }^{17}$ Л. О. Ставицька, Зазнач. джерело.

${ }^{18}$ Там само, с. 220. 
кровопролиттям"; мокра справа „убивство”; криша ${ }^{19}$ — „1. Голова, мізки, здоровий глузд; 2. Зв'язки у владних та правоохоронних структурах"; відмазати - „виправдати когось, зняти звинувачення з когось, підтримати когось, виручити, часто за допомогою грошей”; замовити ${ }^{21}$ — „організувати чиєсь вбивство на замовлення, найняти кілера для вбивства когось”; відмазатися ${ }^{22}$ — „виправдатися, зняти 3 себе звинувачення (як правило, заплативши гроші); ухилятися від якоїсь роботи”; даx 23 — „1. Голова, мізки; 2. Прикриття від рекету, мафії; 3. Зв'язки у владних, бізнесових, правоохоронних структурах"; сходняк ${ }^{24}$ — ,зібрання злодіїв"; показуха 25 — „показування чого-небудь у прикрашеному вигляді, що не відбиває справжньої суті справи, щось показне”, напр.: Перебуваючи на допиті, досвідчена адвокат зрозуміла, що хлопчині „шиють” вчинення тяжких злочинів („Високий замок”, 21.11.2014 - далі В3); „Мокра справа” („Україна молода”, 13.11.2014 — далі УМ); Прокурор Пацкан - кримінальна криша корупиії на Приірпінні („Народна воля”, 11.07.2014 — далі НВ); Роман Федин „кришував” наркотрафік $і$ займався прикриванням фальсифікації виборів до парламенту (В3, 05.01.2015); Роман Федик: Звільнивши з-під варти породіллю, я став “дарувальником” наркотрафіку (B3, 05.01.2015); Прокурор Паикан “відмазує” подєльніка Федорука від кримінальної відповідальності (НВ, 11.07.2014); Співробітники УБОЗ ГУ МВС у Львівській області затримали 31-річного жителя Дрогобича, який ,замовив” два вбивства (B3, 06.11.2014); Через „великі почуття” замовила дружину коханця (В3, 13.03.2015); Коли y Шевченківському районному суді розпочався процес над чотирма правоохорониями з райвідділу міліції, чимало відомих правозахисників у приватних розмовах з кореспондентом “ВЗ” скептично зауважсили, щзо міліціонери “відмажсться" від відповідальності або ж будуть покарані умовними строками ув'язнення (В3, 31.10.2014); Ось і було вирішено влаштувати великий „сходняк” та розібратись із територіальними питаннями („Київ вечірній”, 26.02.15 — далі КВ); Ще й на депутатську “показуху” грошенят підкинули: висвітлення діяльності ВР по ТБ і радіо та офіиійна преса подорожчали на 5 млн. (В3, 15.01.2015).

Кримінальні жаргонізми активно використовують на позначення інших суспільно-політичних понять та процесів, напр.: накрити ${ }^{26}$ — „виявити когось”; здавати 27 — „зраджувати, видавати когось”; дерибан ${ }^{28}$ — „1. Поділ награбованого; 2. Холодно”; розводити ${ }^{29}$ — „обдурювати когось”; прокол ${ }^{30}$ — „невдача, помилка", порівн.: Та бізнес “накрився”, фірма розорилася, дружина пішла геть (B3, 26.10.2014); ...як жартували блогери, бідолаху явно покарали за якийсь “прокол” у роботі... (УМ, 18.11.2014); Депутат: Ахметов давав 25 мільйонів доларів за “здачу” ТЕС у Щасті. У Ахметова заперечують („Українська правда”, 01.02.2015 — далі УП); Антологія земельного дерибану УМ,

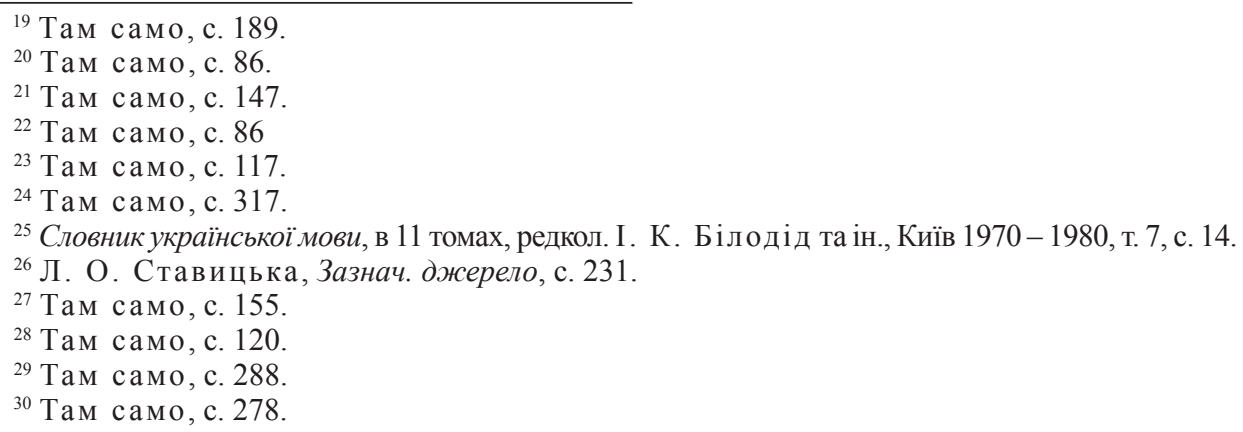


13.03.2015); Держземагенство: змінилася вивіска - дерибан триває („Голос України", 03.03.2015 - далі ГУ); Шістьох жителів міста "розвели" телефонні шахраї („Вісник Переяславщини”, 09.03.2015 — далі ВП).

Часто журналісти надають перевагу розмовній лексиці, оскільки вона має великий потенціал виражальних засобів, створює необхідний експресивний ефект, робить текст конструктивним. Саме через це жаргонізми притаманні текстам на суспільно-політичну тематику (мажор ${ }^{3 l}$ — „матеріально забезпечена молода людина, яка вдає із себе представника еліти й підкреслює свою вищість над іншими”; тушка ${ }^{32}$ — „тіло убитої тварини, дичини невеликого розміру”, „народний депутат, який зрадив фракційні інтереси чи інтереси виборців, змінив фракцію”), напр.: „Мажсори” на районі („Львівська газета”, 02.10.2014 далі ЛГ); Також ніхто з наших кандидатів не став “тушкою”, не перебіг до ворога (ЛГ, 02.10.2014). Запозичуючи одне слово зниженого характеру, автор не просто використовує його як лексичну одиницю, але передає негативне ставлення до процесу, особи чи явища.

Відзначимо, що майже всі елементи жаргонної лексики містять у лексичному значенні певну (передусім несхвальну) оцінку дії, спрямовану на вплив такого матеріалу на читача. За допомогою зазначених слів журналіст може відразу висловити своє ставлення, не звертаючись до допоміжних засобів. Заміна знижених слів нейтральними відповідниками призвела б до простої констатації факту.

У друкованих ЗМІ активно вживають слова, що не мають визначення в словнику, але з огляду на сферу їхнього використання та значення, яке вони виражають у певному мас-медійному тексті, вони належать до жаргонізмів: втемну — „робити щось за закритими дверима, так, щоб ніхто не знав”; сєніч$\kappa и$ — „нововведення, від імені прем'єр-міністра, Арсенія (Сєні) Яценюка”; совєти - „пропагандисти радянської влади”; пипка — „соска-пустушка для дітей”; рімати — „вирішувати власні питання за допомогою грошей чи власного авторитету”; віджати — „забрати щось у когось насильним шляхом”; халявник — „той, хто бажає отримати будь-що, не докладаючи жодних зусиль, задарма”; накачка — „неприродне, штучне наповнення чогось чимось”; ділок — „той, хто вирішує якісь справи, часто нечесним шляхом”, напр.: Бюджет “втемну" (ЛГ, 29.12.2014); Податкові “сєнічки" (ЛГ, 15.01.2015); Хоча "Просвіта" в Україні була створена ще в XIX ст., задовго до того, як сюди прийшли "совєти”, радянська влада оголосила ї̈ ледь не терористичним угрупуванням (ГУ, 15.11.2014); Підсунули народу виборчу “пипку”, щоб той не верещав („Високий замок”, 06.11.2014); Ну і звісно присутність найвідоміших журналістів у провладному блоиі сильно завадить тому ж Балозі чи Жванії "рішати” свої питання (ВУ, 30.01.2015); Павло Шеремета: Домінуюча логіка держави - “віджати" бізнес (УП, 07.11.2014); Це спальний район, одні халявники приходитимуть, - сьорбає каву Олена, 30 років („Газета по-українськи”, 11.11.2014 - далі ГП); Досить згадати незрозумілу і непрозору “накачку” грошима окремих банків навесні [про дії нової влади] („День”, 24.12.2014 - далі Д); Нині боротьба з кримінальними ділками стала особливо актуальною („Урядовий кур'єр", 31.01.2015 - далі УК).

Поява нових жаргонних одиниць укотре свідчить про стрімкий розвиток мови, зокрема мови друкованих 3МІ, ії швидку реакцію на події в суспільстві.

\footnotetext{
${ }^{31}$ Там само, с. 208.

${ }^{32}$ Словник украӥнської мови, ..., , т. 10, с. 331.
} 
Мовна практика молоді вносить до жаргонології нові експресивні одиниці, деякі 3 них можна віднести до сленгізмів. Переважно це слова іншомовного походження ${ }^{33}$. Найвиразнішу групу жаргонних одиниць за емоційноекспресивним насиченням у текстах суспільно-політичної тематики становлять лексеми, які позначають предмети, дії та стани, що характеризують конкретних політиків, державних і громадських діячів ${ }^{34}$, зокрема: тролінг — „розміщення в Інтернеті, на форумах провокаційних повідомлень 3 метою викликати конфлікти між учасниками, образи, війну редагувань”; фейковий від англійського „fake” — „фальшивий, підробний”, напр.: Не треба тролити новообраних депутатів, варто допомогти їм (ЛГ, 14.11.2014); Сміх крізь сльози: у соимережах тролять Гонтарєву через падіння гривні (ГП, 07.11.2014); „Фейкові вибори” (ВВС Україна, 28.10.2014); Усі чутки про призначення Турчинова секретарем РНБО чи Тимошенко міністром МЗС Чорновіл називає фейком (ЛГ, 15.11.2014).

У мові газетної періодики збережена тенденція до активного вживання жаргонної лексики на позначення певних процесів у світі спорту, напр.: наӥжджа$m u^{35}$ — „Поводитися агресивно щодо когось; висувати претензії, погрожувати комусь, застосовувати насильство”; итормити ${ }^{36}$ — „1. Стан алкогольного похмілля; 2. Відчувати неприємні емоції”; кинути ${ }^{37}$ — „виманити, шляхом обману, значну суму грошей, обдурити когось; украсти, відібрати щось у когось"; на голиі $i^{38}$ — „1. Про людину, яка постійно вживає наркотики; 2. Про людину, яка перебуває у стані наркотичного сп'яніння”; договорняк — „спланована дія для задоволення чиїхось потреб (часто за гроші)”, порівн.: Бріггс між “наӥздами” на Кличка здобув 50-ту перемогу нокаутом (ГП, 02.11.2014); Після зміни системи відбору нашу команду почало “итормити” [про стосунки між підопічними у команді] (В3, 12.11.2014); Румуни “кинули” київське “Динамо” (ГУ, 31.01.2015); Спортсмени “на голці” (ЛГ, 16.01.2015); УСФА розслідує “договорняк”? (ГУ, 17.01.2015).

У зв’язку з напруженою ситуацією на сході України мова сучасних ЗМІ поповнилася значною кількістю лексем воєнної тематики. Жаргонних одиниць у таких текстах також додалося, зокрема: злити ${ }^{39}$ — „1. Продати щось; 2. Передати комусь певну інформацію”; мокра справа ${ }^{40}$ — „убивство”; криша ${ }^{41}$ „1. Голова, мізки, здоровий глузд; 2. Зв’ язки у владних та правоохоронних структурах”; відморозок ${ }^{42}$ — „1. Емоційно та інтелектуально недалека людина, часто агресивна; 2. Людина, позбавлена моральних принципів; 3. Член угрупування рекетирів, який бере участь у бойових операціях"; злити ${ }^{43} \_, 1$. Продати щось; 2. Передати комусь певну інформацію”; накрити ${ }^{44}$ — „виявити когось”; втюха$m u$ — „нав’язати комусь щось не потрібне”; спец — „те саме, що й спеціаліст”; шаровий „1. Безкоштовний, той, що дістався даром; 2. Легкий”, порівн.: ОБСС злила росіянам розташування українських позицій (В3, 11.11.2014); У нього

${ }_{33}^{33}$ М. I. Навальна, Динаміка лексикону української періодики початку XXI ст., Київ 2011, с. 239.

${ }^{34}$ Там само, с. 239.

35 Л. О. Ставицька, Зазнач. джерело, с. 229.

${ }^{36}$ Там само, с. 382.

${ }^{37}$ Там само, с. 171 .

${ }^{38}$ Там само, с. 106.

39 Там само, с. 158 .

${ }^{40}$ Там само, с. 220.

${ }^{41}$ Л. О. Ставицька, Зазнач. джерело, с. 189.

${ }^{42}$ Там само, с. 87.

${ }^{43}$ Там само, с. 158 .

${ }^{44}$ Там само, с. 231. 
є армія “кримська самооборона”, він пам'ятає свою участь у “мокрих” справах $і$ всі його уміння управляти своєю та захоплювати чужу власність, знаходять своє застосування хоча б в постійних ініціативах його уряду "націоналізувати” той чи інший кримський об'єкт (censor.net, 11.11.2014); Для ичього у неї є все - порти, не підконтрольність міжнародним інститутам, влада в руках криміналітета, “криша” — ФСБ, непрозорі багатомільйонні транші з російської казни [про кримську зону] (censor.net, 11.11.2014); Хоча “відморозків" серед ополченців багато, десь відсотків 10 - констатує журналіст (Д, 16.01.2015); Бараки з рабами цілодобово охороняли місцеві “відморозки” з вівчарками (В3, 09.11.2014); Шарових квартир для воєнних більше не буде (УГ, 20.03.15); Російські офічери “злили” Україні дані про військових-зрадників у Криму (ГП, 18.02.2015); У Луганській області поновили обстріли - Попасну двічі “накрили” з мінометів („Сегодня”, 23.02.2015); Тепер його ключове завдання (Путіна) - “втюхати” самопроголомені республіки Украӥні (УП, 18.11.2014); Російські “специ” зайнялися „Новоросією”: пронумерували бан$\partial u(\Gamma \Pi, 16.01 .2015)$.

Лексема накривати першочергово має значення „виявляти когось”, а вживання іiі для позначення певних процесів на воєнному сході надає їй іншого смислового відтінку: у цьому разі йдеться про „посилення обстрілів 3 боку бойовиків".

Словник жаргонізмів не подає тлумачення лексеми втюхати, але 3 огляду на сферу iï використання в певних газетних текстах, можемо зазначити, що йдеться про „намагання комусь щось нав’язати”, як, напр., В. Путін робить спробу нав'язати самопроголошені республіки Україні; ті так звані республіки, що тепер потребують значного рефінансування, і под.

Через нелогічні кроки сучасної влади їі жорстко критикують на шпальтах газет. Аби підкреслити негативне ставлення до можновладців, автори також активно використовують жаргонну лексику, напр.: відкоситu $u^{45}-$,ухилитися від чогось”; лохотрон ${ }^{46}$ — „безпрограшна лотерея, яку влаштовують шахраї на вулиці"; шишка $a^{47}$ — „1. Чоловічий статевий орган; 2. Гаманець 3 грішми; 3. Впливова, авторитетна особа"; посадити на голку ${ }^{48}$ — „залучити до наркоманії когось"; наӥжджати ${ }^{49}$ — „поводитися агресивно щодо когось; висувати претензії, погрожувати комусь, застосовувати насильство”; фанерний ${ }^{50}-, 1$, Який виконується під фонограму; 2. Фальшивий, підроблений”; прольот ${ }^{51}$ — „невдача, прорахунок”; понт ${ }^{52}$ — „1. Обман, хитрість, видимість чогось; 2. Прибуток; 3. Самовпевнена поведінка, самовихваляння, апломб, гонор; 4. Вигода, перевага, прибуток", порівн.: Державний переворот - ие коли київькі прокурори ідуть у зону АТО на кілька днів, щзоб одержати статус учасника бойових дій $i$ “відкосити” від люстрації (ВУ, 14.11.2014); Ось такою люстрацією “лохотронять” українців, видаючи ї̈ за тотальне очищення влади (В3, 06.11.2014); I є шишка з Держкомзему, яка не ходила у партбосах, але має сумнівну графу в біографії... (B3, 06.11.2014); Волинець: Росія хоче підсадити Украӥну ше

\footnotetext{
45 Там само, с. 86.

46 Там само, с. 206.

47 Там само, с. 376.

48 Там само, с. 106.

49 Там само, с. 229.

50 Там само, с. 336 .

${ }^{51}$ Там само, с. 279.

52 Там само, с. 267.
} 
й на вугільну “голку” (В3, 08.11.2014); Наступного дня після “наӥзду” відомства Віталія Яреми, правління “Укрнафти” окремо попередило посадових осіб Міненерговугілля про відповідальність („Українська правда”, 05.11.2014); Головний же “фанерний” кубок невдах (за груповий проліт над Верховною Радою) по праву належить сімейній піраміді ККК (В3, 31.10.2014); Однією з найбільших несподіванок можна вважати "прольот" "Громадської позииії" Анатолія Грищенка (В3, 31.10.2014); Навіть за неперевершеного любителя "понтів" Януковича сума була скромнішою - 302 млн. грн (B3, 15.01.2015).

Лексема фанерний - „фальшивий; який виконується під фонограму” — набуває в текстах періодики іншого відтінку, коли вживається в переносному значенні для позначення невдач у планованих діях роботи Верховної Ради. Власне в цьому разі вона перегукується із загальновідомим виразом „Пролетіти як фанера над Парижем", тобто „не змогти чогось зробити”. Уживання сталого жаргонного вислову „посадити на голку” в переносному значення підкреслює ймовірну залежність України від російського вугілля.

Журналісти не оминають увагою й політичну ситуацію, що склалася в Російській Федерації, та, аби наголосити на абсурдності і її показовості, нерідко вживають жаргонізми, зокрема: шістка ${ }^{53}$ - „1. Офіціант; 2. Підлабузник; 3. Найнижча ланка в ієрархії злочинного світу; 4. Людина, яка виконує некваліфіковану або брудну роботу; 5 . Людина 3 невисоким соціальним статусом"; розводити ${ }^{54}$ — „обдурювати когось”; пурга ${ }^{55}$ — „беззмістовна розмова, теревені”, напр.: Хвалькуваті “шістки” Кремля (УМ, 05.11.2014); Путін легко “розвів" самовпевненого Порошенка (УМ, 18.11.2014); Таку “пургу” гнав, зокрема, керівник зовнішньополітичного комітету Держдуми Олексій Пушков (В3, 28.01.2015): йдеться про долю Савченко, яку ніби має вирішувати російський суд.

Отже, у сучасному газетному дискурсі активно використовують жаргонізми, що надають текстам ЗМІ емоційно-експресивного забарвлення. Найчастіше жаргонізми вживають, аби надати газетним текстам негативної тональності, засудити ті дії чи процеси, що відбуваються в суспільстві.

Однак уживання жаргонної лексики в літературній мові розхитує іiі норми, засмічує і лібералізує іiі. Разом з тим, простежуємо "розмивання" меж між стилями, що негативно позначається на структурі мови, іiі стилістичному та лексико-семантичному рівнях.

Як зазначалося, використання в текстах друкованих 3МI жаргонних одиниць указує на спосіб моделювання пейоративного, зневажливого значення, надання оцінки певному процесу, особистості чи дії без додаткового використання інших виражальних засобів.

У статті також здійснено спробу систематизувати жаргонну лексику за тематичними групами, визначити стилістичну диференціацію жаргонної дексики та сферу іiї застосування, але ця наукова розвідка не вичерпує всієї проблематики дослідження мови ЗМІ й потребує відповівідного продовження.

\footnotetext{
${ }^{53}$ Там само, с. 376.

${ }^{54}$ Там само, с. 288.

55 Там само, с. 281.
} 